\begin{tabular}{|c|c|c|}
\hline \multirow{2}{*}{ P-ISSN: } & & \multirow{2}{*}{ Vol. 6, No. 2, } \\
\cline { 2 - 3 } $2355-8245$ & JPIPS : JURNAL PENDIDIKAN ILMU PENGETAHUAN SOSIAL & Juni 2020 \\
E-ISSN: & Tersedia secara online: http://ejournal.uin-malang.ac.id/index.php/jpips & Halaman: $89-96$ \\
\cline { 2 - 2 } $2614-5480$ & & \\
\cline { 2 - 3 } & & \\
\hline
\end{tabular}

\title{
PERANAN METODE TUGAS TERSTRUKTUR DALAM MENINGKATKAN HASIL BELAJAR GEOGRAFI
}

\author{
Kurnia Maulidi Noviantoro \\ Universitas Islam Zainul Hasan Genggong Probolinggo \\ maulana.novianto@gmail.com
}

Diterima: 26-02-2020.; Direvisi: 27-05-2020; Disetujui: 08-06-2020

Permalink/DOI: $10.15548 /$ jpips.v6i2.8880

\begin{abstract}
Abstrak: Tujuan penelitian ini adalah untuk melakukan telaah bagaimana peran tugas terstruktur terhadap peningkatan hasil belajar geografi. Penelitian ini menggunakan metode studi kepustakaan. Pendekatan dilakukan dengan analisis content. Tahapan penelitian ini dilakukan dengan pengumpulan data dari berbagai macam literatur, dianalisis, dinilai, dan akhirnya ditarik kesimpulan. Temuan penelitian yaitu tugas terstruktur sangat berperan atau berdampak posistif dalam meningkatkan hasil belajar geografi, serta dapat memacu motivasi peserta didik untuk belajar. Selain itu beberapa temuan lain juga mengungkapkan, secara umum tugas terstruktur memiliki peranan dalam meningkatkan hasil belajar serta prestasi peserta didik, meskipun pada tingkatan dan jenis mata pelajaran yang berbeda.
\end{abstract}

\section{Kata Kunci: peranan; tugas terstruktur; hasil belajar}

Abstract: The purpose of this research is to examine how the role of structured tasks to improve learning outcomes in geography. This research uses the literature study method. The approach is carried out with content analysis. The stages of this research are carried out by collected from various kinds of literature, analyzed, assessed, and finally drawn conclusions. The research findings conclude that structured assignments play a very positive role or impact in improving geography learning outcomes, and can stimula te students' motivation to learn. In addition, several other findings also revealed that in general structured tasks have a role in improving student learning outcomes and achievements, even in different levels and types of subjects.

Keywords: role; structured task; learning outcomes 


\section{PENDAHULUAN}

Diterapkannya Kurikulum 2013 (K-13) mulai tahun 2013 lalu, guru tidak dapat lagi tetap bertahan dengan pola mengajar kuno yakni menjadi pusat aktivitas pembelajaran di kelas atau yang biasa disebut teacher center (Dewantoro, 2017). Metode ini sangat melekat dan susah ditinggalkan oleh kebanyakan guru di sekolah. Teacher Center dipertahankan karena dinilai masih paling praktis dan tidak menyita banyak waktu. Akan tetapi, di sisi lain dengan tetap eksisnya metode kuno tersebut, menyebabkan peserta didik cenderung bosan dan akhirnya kurang tertarik terhadap pembelajaran sehingga berpengaruh pada minat serta pencapaian hasil belajar mereka.

Metode pembelajaran yang selama ini masih sering digunakan di sekolah adalah metode ceramah dan diskusi kelompok besar, dengan metode ceramah, interaksi antarpeserta didik kemungkinan sangat kecil, sehingga pengalaman belajarnya terbatas. Penggunaan metode ceramah sebagian besar aktivitas belajar-mengajarnya dilakukan oleh guru, peserta didik bertindak pasif dan kurang memperoleh kesempatan untuk mengembangkan kreatifitas, dalam metode tersebut, guru lebih banyak berbicara, menjelaskan, menjawab pertanyaan, bahkan menyelesaikan soal-soal sendiri daripada memberikan kesempatan kepada peserta didik untuk berpikir, memahami, dan menganalisis sendiri apa yang sedang dipelajari. Sedangkan diskusi kelompok besar, peserta didik akan lebih intens saling melengkapi berbagi pikiran dan informasi guna mencapai tujuan yang telah dicanangkan (Usman, 2008). Pada praktiknya, terkadang masih terdapat superioritas peserta didik tertentu sehingga beberapa dari mereka yang lain cenderung pasif karena malu atau kurang percaya diri mengemukakan idenya. Hal tersebut berakibat pada keaktifan mereka yang tidak merata dan seringkali pembicaraan atau arah jalannya diskusi menyimpang. Akhirnya berdampak pada hasil belajar yang dicapai cenderung rendah. Fakta yang ada saat ini, metode ceramah sudah terbiasa menjadi senjata utama guru dalam aktivitas pembelajaran karena dirasa paling mudah dan sederhana. Kondisi demikian menyebabkan mereka kebanyakan merasa kesulitan untuk memilih metode yang tepat saat mengajar, termasuk untuk mata pelajaran geografi.

Pemberian tugas terstruktur akan memberikan kesempatan kepada peserta didik untuk belajar mandiri tidak hanya tergantung kepada bimbingan guru (Jumiatun, Samad, \& Ma'ruf 2016). Tugas terstruktur dapat diberikan sebelum atau sesudah materi diajarkan. Tugas terstruktur diberikan sebelum aktivitas pembelajaran bertujuan untuk memantapkan kemampuan peserta didik yang berupa rangsangan, respon dan kesiapan belajar. Pemberian tugas setelah proses aktivitas pembelajaran dilakukan untuk mengukur kemampuan yang sudah terbentuk sesudah melalui tahapan terstruktur dengan harapan akan terus tertanam kuat dan bertahan lama pada peserta didik.

Pemberian tugas terstruktur menuntut peserta didik untuk lebih berpikir kritis saat menjawab pertanyaan yang diberikan guru. Berdasarkan temuan penelitian yang dilakukan oleh Rahma dinyatakan bahwa hasil belajar geografi peserta didik meningkat melalui pemberian tugas terstruktur (Rahma, 2018). Perolehan hasil belajar yang awalnya 56\% untuk ketuntasan mencapai KKM dengan rata-rata nilai 67, kemudian mengalami peningkatan menjadi $81 \%$ pencapaian KKM dengan rata-rata nilai 76 setelah melalui beberapa tahapan pemberian tugas terstruktur. Hal ini menjadi dasar tujuan peneliti untuk melakukan telaah bagaimana peran tugas terstruktur terhadap peningkatan hasil belajar geografi. Harapan penelitian ini akan dapat menjadi acuan untuk para guru dalam aktivitas pembelajaran di kelas. 


\section{METODE}

Penelitian ini termasuk jenis penelitian studi kepustakaan. Studi kepustakaan yaitu melaksanakan penelitian dengan cara mengumpulkan, membaca, dan menganalisis sumber-sumber bacaan yang berhubungan dengan permasalahan objek kajian penelitian. Adapun sumber bacaan yang dapat dijadikan bahan telaah analisis dapat berupa buku, literatur, internet, karya ilmiah, catatan, atau pun laporan-laporan yang masih berhubungan dengan topik masalah (Nazir, 2011). Selain itu penelitian ini juga menggunakan metode analisis data kualitatif yakni data penelitian yang menghasilkan data deskriptif berupa tulisan. Data dianalisis dengan analisis content dan deskripsi isi. Analisis content adalah cara untuk mempelajari dan memahami makna sumber-sumber yang memiliki korelasi dengan penilaian. Sedangkan deskripsi adalah cara untuk memberikan penjelasan data.

\section{HASIL DAN PEMBAHASAN \\ Hasil}

Tugas terstruktur akan memberikan kesempatan kepada peserta didik untuk belajar mandiri tidak hanya tergantung kepada bimbingan guru, di samping itu, metode tugas terstruktur mendorong peserta didik untuk lebih aktif dalam setiap proses pembelajaran, menjadikannya sebagai individu yang berani mengemukakan pendapat, mampu memecahkan masalah yang dihadapi, serta mampu berkomunikasi dengan orang lain untuk mendapatkan informasi yang dibutuhkan sehingga memiliki pemahaman informasi dengan benar. Berdasarkan kegiatan penelitian yang dilakukan oleh Rahma, hasil penelitian menunjukkan bahwa kegiatan pembelajaran geografi melalui metode pemberian tugas terstruktur telah menunjukkan hasil yang cukup baik (Rahma, 2018).

Tugas terstruktur dapat diberikan sebelum atau sesudah materi diajarkan. Tugas terstruktur diberikan sebelum aktivitas pembelajaran bertujuan untuk memantapkan kemampuan peserta didik yang berupa rangsangan, respon, dan kesiapan belajar. Pemberian tugas setelah proses aktivitas pembelajaran dilakukan untuk mengukur kemampuan yang sudah terbentuk sesudah melalui tahapan terstruktur dengan harapan akan terus tertanam kuat dan bertahan lama pada peserta didik. Hal ini didukung oleh pendapat Sujono (dalam Syuhada, 2012) yang menyatakan bahwa memberi tugas sesudah materi diajarkan dimaksudkan agar peserta didik dapat lebih memahami konsep-konsep yang telah diajarkan secara mendalam.

Tugas terstruktur di sekolah juga digunakan untuk memperbaiki pemahaman peserta didik setelah guru memberikan materi pelajaran. Peran guru sebagai fasilitator dan teman belajar dalam rangkaian tugas terstruktur dapat mengembangkan kemandirian belajar peserta didik. Pemberian tugas terstruktur dapat mendorong peserta didik lebih aktif dan memberikan pengaruh positif, sehingga mereka lebih banyak bekerja daripada hanya sekedar mendengar dan menerima informasi. Guru merancang tugas sekaligus menentukan batas akhir penyelesian dalam pembelajaran semata-mata untuk mencapai standar kompetensi yang ada. Jika pemahaman materi dan konsep telah tertanam dalam diri peserta didik, maka di dalam kegiatan evaluasi akhir, mereka akan mendapatkan hasil belajar yang maksimal.

Konsep ini juga didukung oleh penelitian yang telah dilakukan Warsiyam di SDN Kutamendala 4 Brebes, Jawa Tengah. Penelitiannya menyimpulkan bahwa metode pembelajaran dengan tugas terstruktur berpengaruh positif dalam meningkatkan prestasi dan hasil belajar peserta didik. Perolehan hasil belajar peserta didik yang pada siklus awal hanya mencapai $66,67 \%$ untuk ketuntasan mencapai KKM, mengalami 
peningkatan menjadi $88,89 \%$ setelah melalui beberapa siklus dalam penerapan metode tersebut. Selain itu penerapan pembelajaran seperti ini juga memiliki dampak baik lain yakni meningkatkan gairah, semangat, dan motivasi belajar peserta didik (Warsiyam, 2016).

Penelitian serupa juga dilakukan oleh Surie yang membuktikan bahwa terdapat korelasi positif antara metode pembelajaran tugas terstruktur dengan hasil belajar serta minat belajar peserta didik (Surie, Maharta, \& Rosidin, 2014). Sejalan dengan itu pula, Ibrahim mengungkapkan terdapat perbedaan yang mencolok dari hasil belajar peserta didik apabila di suatu kelas diterapkan metode pemberian tugas terstruktur, sementara di kelas yang lain diberikan perlakuan pembelajaran konvensional (Ibrahim, Yani, \& Haris, 2016). Kesimpulan penelitiannya mencatat skor rata-rata hasil belajar peserta didik mengalami peningkatan secara signifikan, dengan demikian, meskipun dilakukan pada tingkatan dan jenis pelajaran yang berbeda, namun secara garis besar metode tugas terstruktur telah terbukti berpengaruh baik terhadap hasil belajar peserta didik.

Hasil belajar peserta didik mengalami peningkatan melalui pemberian tugas terstruktur. Dari hasil penelitian ini menunjukkan bahwa peranan metode tugas terstruktur meningkatan hasil belajar geografi. Perolehan nilai geografi peserta didik kelas XI IPS 3 SMA 3 Kendari yang awalnya 56\% dengan rata-rata nilai 67, mengalami peningkatan menjadi $81 \%$ dengan rata-rata nilai 76 dalam pencapaian ketuntasan KKM setelah melalui beberapa tahapan pemberian tugas terstruktur (Rahma, 2018). Peranan metode tugas terstruktur dalam meningkatan hasil belajar geografi dapat dilihat pada tabel berikut:

Tabel. 1 hasil belajar geografi meningkat setelah dilakukan metode tugas terstruktur

\begin{tabular}{llll}
\hline & Peserta didik & Rata-Rata Nilai & KKM \\
\hline Tahap I & $56 \%$ & 67 & 75 \\
\hline Tahap II & $81 \%$ & 76 & 75 \\
\hline
\end{tabular}

\section{Pembahasan}

Metode tugas terstruktur berbeda dengan tugas rumah (PR). Seringkali pemberian tugas(resitasi) disamakan dengan tugas yang harus diselesaikan di rumah. Padahal ruang lingkup atau domain dari kedua tugas di atas tidak sama. Pemberian tugas (resitasi) memiliki ruang lingkup yang lebih luas. Metode resitasi (penugasan) adalah metode yang dilakukan oleh guru kepada peserta didik dengan memberikan tugas tertentu dalam suatu rangkaian pembelajaran agar mereka belajar (Djamarah \& Zain, 2010). Sementara penugasan terstruktur adalah aktivitas pembelajaran yang dirancang oleh guru untuk peserta didik guna mencapai kompetensi tertentu dan terikat oleh waktu yang sudah ditentukan guru. Aktivitas tersebut antara lain dapat berupa pemberian tugas individu atau pun kelompok.

Tugas terstruktur berbeda dengan tugas tidak terstruktur. Tugas tidak terstruktur merupakan aktivitas pembelajaran yang dirancang oleh guru untuk peserta didik guna mencapai kompetensi tertentu, namun dalam penentuan waktunya terdapat intervensi peserta didik, maka dari itu, perbedaan yang paling mendasar antara keduanya adalah penentuan waktu penyelesaiannya. Tugas dapat dikatakan terstruktur jika diselesaikan dan dikumpulkan peserta didik dengan batas yang telah ditentukan oleh guru. Biasanya tempo yang ditentukan lebih singkat. Sementara, disebut sebagai tugas tidak terstruktur jika terdapat kesepakatan antara guru dengan peserta didik terkait waktu penyelesaian sehingga tempo batas pengumpulannya biasanya lebih lama dan variatif. Misalnya pengumpulannya seminggu sebelum ujian semester atau dijadikan sebagai bahan tambahan tugas tengah semester (Kholil, 2010). 
Metode tugas terstruktur memaksa peserta didik untuk menyelesaikan tugas yang diberikan melalui pencarian referensi dari berbagai sumber, setelah itu hasilnya akan diperiksa oleh guru untuk diketahui tingkat kebenaran jawabannya, dalam konteks penugasan, tugas terstrukur sering disamakan dengan pekerjaan rumah (PR), yakni tugas khusus untuk peserta didik yang harus diselesaikan di luar jam pelajaran di kelas. Padahal keduanya sangat berbeda, terutama terkait dengan waktu dan tempat. Tugas terstruktur merupakan aktivitas pembelajaran peserta didik yang dapat meningkatkan kemandirian mereka untuk lebih giat belajar dan saat penerapannya peran guru hanyalah sebagai fasilitator atau pun teman belajar. Pemberian tugas terstruktur memberikan pengaruh positif terhadap peserta didik, mendorongnya agar aktif, lebih banyak bekerja daripada hanya sekedar mendengar dan menerima informasi. Tugas terstruktur sangat penting dalam pengajaran karena tugas ini dapat digunakan untuk meninjau pelajaran baru, mengingat pelajaran yang sudah diajarkan, memecahkan suatu masalah dan sebagainya sehingga dapat menunjang pemahaman peserta didik tentang konsep geografi yang sedang dipelajarinya.

Proses pembelajaran pada tugas terstruktur bertujuan memberikan peluang bagi peserta didik mempelajari atau menyelidiki suatu topik dari berbagai sumber. Pemberian tugas terstruktur ini meliputi semua bentuk tugas yang berkaitan dengan materi yang harus dikerjakan. Harapannya, agar peserta didik dapat memperoleh keterampilan, kepekaan, dan memberikan kebiasaan belajar kepada mereka sehingga dapat menunjang pemahaman tentang konsep ilmu pengetahuan yang sedang dipelajarinya.

Pemberian tugas oleh guru tidak bisa secara sembarangan. Hal ini dimaksudkan agar tugas tersebut dapat dikerjakan dengan baik oleh peserta didik. Adapun syaratsyarat pemberian tugas yang baik menurut penulis, antara lain: 1) setiap tugas harus dipikirkan dan dipersiapkan terlebih dahulu oleh guru; 2) tugas harus jelas dan tegas; 3) setelah tugas diberikan, guru harus menjelaskan kesulitan-kesulitan yang mungkin dihadapi dalam pengerjaannya nanti; 4) tugas harus dipahami oleh setiap peserta didik; 5) tugas harus sesuai dengan kemampuan dan minat peserta didik; 6) guru harus bisa meyakinkan bahwa tugas itu bermakna bagi peserta didik. Sejalan dengan itu, Soetomo juga mengemukakan bahwa saat pemberian tugas, hendaknya terlebih dahulu guru memberitahu kepada peserta didik tentang tujuan pembelajaran yang akan dicapai dan secara rinci menjelaskan petunjuk pengerjaan tugas tersebut (Soetomo, 1993), dengan demikian peserta didik akan dapat mengerjakan secara mudah dan memperoleh hasil belajar yang optimal.

Metode pemberian tugas terstruktur memiliki kelebihan dan kekurangan (Fitriyah \& Indraswari, 2018). Kelebihan metode pemberian tugas terstruktur diantaranya yaitu: 1) ilmu dan pengetahuan yang diperoleh peserta didik saat proses pembelajaran(pengerjaan tugas) akan membekas dan bertahan lama menjadi pengalaman berharga dalam hidupnya; 2) dapat menumbuhkan rasa tanggung jawab, keberanian, dan percaya diri peserta didik; 3) lebih merangsang peserta didik dalam melakukan aktivitas belajar; 4) dapat mengembangkan kemandirian di luar pengawasan guru; serta 5) dapat mengembangkan kreativitas peserta didik.

Selain terdapat beberapa kelebihan, pemberian tugas terstruktur juga terdapat kelemahan. Kelemahan-kelemahan dalam pemberian tugas terstruktur, di antaranya yaitu: 1) peserta didik biasanya melakukan kecurangan, dalam hal ini mereka hanya mencontoh pekerjaan teman; 2) peserta didik sulit dikontrol, apakah benar ia mengerjakan tugas ataukah orang lain; 3) sering memberikan tugas yang monoton (tidak 
bervariasi) dapat menimbulkan kebosanan; dan 4) sukar memberikan tugas yang memenuhi perbedaan individual. Kelemahan ini haruslah dapat diatasi dengan menerapkan langkah-langkah tugas terstruktur. Di samping itu, dalam memberikan tugas seorang guru dituntut untuk memiliki kreativitas dan keluwesan yang baik.

Penerapan metode tugas terstruktur juga haruslah memperhatikan keadaan peserta didik. Misalnya saat proses pembelajaran di sekolah, peserta didik tidak selalu dalam keadaan prima. Hal ini berdampak pada hasil belajar yang mereka capai. Banyak faktor yang mengakibatkan kondisi hasil belajar mereka fluktuatif. Slameto (dalam Suwardi, 2012) mengungkapkan bahwa setidaknya terdapat enam faktor yang bisa mempengaruhi hasil belajar peserta didik, yaitu:

1) Faktor jasmaniah meliputi kesehatan dan cacat tubuh. Jika peserta didik dalam proses pembelajaran memiliki kesehatan yang prima, maka hasil belajar yang dicapai akan maksimal.

2) Faktor psikologi meliputi intelegensi, minat, perhatian, bakat, motivasi, kesiapan, kecakapan, dan kedewasaan.

3) Faktor keaktifan di masyarakat

Kesibukan yang berupa aktivitas rutin akan berpengaruh terhadap kondisi peserta didik. Misalnya saat mereka super aktif dalam organisasi baik di sekolah atau pun di luar, maka akan cenderung dapat mudah lelah. Kondisi fisik yang terlalu lelah akan berdampak pada proses pembelajaran, akibatnya juga akan berpengaruh terhadap hasil belajar yang mereka capai.

4) Faktor lingkungan keluarga

Keluarga merupakan lingkungan pertama yang menentukan dan membentuk karakter seorang individu. Lingkungan keluarga juga turut berperan dalam perkembangan budi pekerti, sikap, akhlak, bahkan moral peserta didik. Oleh karenanya begitu vitalnya keharmonisan keluarga sebagai jantung utama pendidikan bagi peserta didik untuk dapat mencapai hasil belajar yang optimal.

5) Faktor lingkungan sekolah

Lingkungan sekolah yang nyaman akan berperan dalam penentuan hasil belajar peserta didik. Misalnya kondisi kelas yang bersih, sarana lengkap, keramahan guru, pertemanan yang akrab akan semakin menambah suasana belajar yang baik. Sehingga, akan memberikan dorongan mereka untuk belajar lebih giat. Jika peserta didik telah giat dalam belajar, maka pencapaian dan keberhasilan belajar juga akan tercapai dengan baik.

6) Faktor lingkungan masyarakat

Lingkungan tempat tinggal peserta didik juga berpengaruh terhadap hasil belajar. Misalnya tempat tinggal yang berada di sekitar pemukiman kumuh yang terdiri dari orang-orang kurang terpelajar, banyak preman berkeliaran, dan memiliki kebiasaan negatif, maka sedikit banyak akan berpengaruh buruk pada mereka. Akibatnya belajarnya menjadi terganggu, dan bahkan kehilangan semangat belajar yang akan berpengaruh langsung terhadap hasil serta prestasi belajar yang diperoleh. Begitu pula sebaliknya, jika anak (peserta didik) berada di lingkungan orang-orang terpelajar yang baik-baik, maka pengaruh itu dapat menjadi dorongan semangat untuk belajar lebih giat.

Hasil belajar tidak diperoleh secara instan. Usaha yang keras, gigih, tekun dan pantang menyerah akan membuahkan hasil belajar yang optimal. Melalui upaya tersebut, seorang individu akan berpeluang meraih hasil belajar yang baik. Ukuran hasil belajar didasari dengan perubahan tingkah laku, pengetahuan, pemahaman, sikap dan 
keterampilan yang meningkat. Dalam bukunya Dimyati dan Mudjiono yang berjudul "Belajar dan Pembelajaran" disampaikan bahwa terdapat dua perspektif hasil belajar. Yakni perspektif hasil belajar dari guru dan perspektif hasil belajar peserta didik. Guru berpandangan bahwa terselesaikannya bahan pelajaran serta proses pembelajaran merupakan hasil belajar. Sedangkan dari sudut pandang peserta didik, meningkatnya mental mereka ke arah yang lebih baik dibanding sebelum melalui proses pembelajaran merupakan hasil belajar yang sesungguhnya. Meskipun dalam penilaiannya masih terdapat beberapa kriteria pembagian, antara lain ranah kognitif, afektif, dan psikomotor (Dimyati \& Mudjiono, 2010).

Berdasarkan pembahasan di atas, dari penelitian ini dihasilkan bahwa pembelajaran geografi dengan menggunakan metode tugas terstruktur memiliki peranan yang penting dalam meningkatkan hasil belajar peserta didik, antara lain dibuktikan dengan penelitian oleh Rahma yang mengungkap hasil belajar geografi peserta didik kelas XI IPS 3 SMA 3 Kota Kendari mengalami peningkatan melalui pemberian tugas terstruktur (Rahma, 2018). Selain itu beberapa temuan lain juga mengungkapkan, secara umum tugas terstruktur memiliki peranan yang baik dalam meningkatkan hasil belajar serta prestasi peserta didik, meskipun pada tingkatan dan jenis mata pelajaran yang berbeda, oleh sebab itu, hasil penelitian ini dapat dijadikan sebagai acuan atau pun rekomendasi bagi guru untuk dapat menerapkan metode tugas terstruktur pada peserta didik, terutama pada pelajaran geografi.

\section{KESIMPULAN}

Metode penugasan terstruktur adalah aktivitas pembelajaran yang dirancang oleh guru untuk peserta didik guna mencapai kompetensi tertentu dan terikat oleh waktu yang sudah ditentukan guru. Aktivitas tersebut antara lain dapat berupa pemberian tugas individu atau pun kelompok. Tugas terstruktur merupakan aktivitas pembelajaran peserta didik yang dapat meningkatkan kemandirian mereka untuk lebih giat belajar dan saat penerapannya peran guru hanyalah sebagai fasilitator atau pun teman belajar. Pemberian tugas terstruktur memberikan pengaruh positif terhadap peserta didik, mendorongnya agar aktif, lebih banyak bekerja daripada hanya sekedar mendengar dan menerima informasi. Tugas terstruktur sangat penting dalam pengajaran karena tugas ini dapat digunakan untuk meninjau pelajaran baru, mengingat pelajaran yang sudah diajarkan, memecahkan suatu masalah dan sebagainya sehingga dapat menunjang pemahaman peserta didik tentang konsep Geografi yang sedang dipelajarinya.

Tugas terstruktur bertujuan memberikan peluang bagi peserta didik mempelajari atau menyelidiki suatu topik dari berbagai sumber. Pemberian tugas terstruktur ini meliputi semua bentuk tugas yang berkaitan dengan materi yang harus dikerjakan. Harapannya, agar peserta didik dapat memperoleh keterampilan, kepekaan, dan memberikan kebiasaan belajar kepada mereka sehingga dapat menunjang pemahaman tentang konsep ilmu pengetahuan yang sedang dipelajarinya. Tugas terstruktur sangat berperan dalam meningkatkan hasil belajar geografi. Hal ini didukung oleh Rahma bahwa hasil belajar peserta didik meningkat melalui pemberian tugas terstruktur. Perolehan hasil belajar geografi peserta didik kelas XI IPS 3 SMA 3 Kendari yang awalnya 56\% untuk ketuntasan mencapai KKM dengan rata-rata nilai 67 , kemudian mengalami peningkatan menjadi $81 \%$ pencapaian KKM dengan rata-rata nilai 76 setelah melalui beberapa tahapan pemberian tugas terstruktur (Rahma, 2018). Senada dengan itu, Warsiyam pada penelitiannya di tingkat sekolah dasar dengan mata pelajaran berbeda juga mengungkapkan bahwa melalui metode tugas terstruktur, banyak 
peserta didik meningkat prestasi dan hasil belajarnya yang ditandai dengan tingginya angka ketuntasan. Perolehan hasil belajar peserta didik yang pada siklus awal hanya mencapai $66,67 \%$ untuk ketuntasan mencapai KKM, mengalami peningkatan menjadi $88,89 \%$ setelah melalui beberapa siklus dalam penerapan metode tersebut (Warsiyam, 2016). Dengan demikian secara umum tugas terstruktur juga memiliki peranan yang baik dalam meningkatkan hasil belajar serta prestasi peserta didik, meskipun pada tingkatan dan jenis mata pelajaran yang berbeda.

\section{DAFTAR PUSTAKA}

Dewantoro, H. (2017). Paradigma Kurikulum 2013. Diambil dari https://silabus.org/paradigma-kurikulum-2014/

Dimyati \& Mudjiono. (2010). Belajar dan Pembelajaran. Jakarta: Direktorat Jenderal Pendidikan Tinggi Departemen Pendidikan dan Kebudayaan.

Djamarah, S. B., \& Zain, A. (2010). Strategi Belajar Mengajar. Jakarta: Rineka Cipta.

Fitriyah, L. M., \& Indraswari, N. F. (2018). Pengembangan Kemampuan Koneksi Matematis dan Daya Nalar Mahasiswa melalui Pemberian Tugas Terstruktur dan Diskusi Menggunakan Aplikasi Whatsapp. SIGMA, 4(1), 20-28.

Ibrahim, A. A., Yani, A., \& Haris, A. (2016). Pengaruh Penggunaan Metode Pemberian Tugas Terstruktur Terhadap Hasil Belajar Fisika Kelas XI SMA Negeri 22 Makassar. Jurnal Pendidikan Fisika, 3(2), 150-157.

Jumiatun, Samad, A., \& Ma'ruf. (2016). Upaya Meningkatkan Hasil Belajar Fisika Melalui Pemberian Tugas Terstruktur Disertai Umpan Balik pada Model Pembelajaran Langsung Peserta Didik Kelas VIIA SMP Negeri 1 Bontonompo Kabupaten Gowa. Jurnal Pendidikan Fisika, 4(2), 185-196.

Kholil, M. (2010). Tugas Mandiri Terstruktur dan Tidak Terstruktur. Diambil dari http://hali14.wordpress.com/2010/06/18/tugas-mandiri-terstruktur-dan-tidakterstruktur-3/

Nazir, M. (2011). Metode Penelitian. Jakarta: Ghalia Indonesia.

Soetomo. (1993). Dasar-Dasar Interaksi Belajar Mengajar. Surabaya: Usaha Nasional.

Surie, A. N., Maharta, N., \& Rosidin, U. (2014). Hubungan Pembelajaran Berbasis Tugas Terstruktur terhadap Hasil Belajar dan Minat Belajar Fisika. Jurnal Pembelajaran Fisika, 2(7), 85-96.

Suwardi, D. R. (2012). Faktor-Faktor yang Mempengaruhi Hasil Belajar Siswa Kompetensi Dasar Ayat Jurnal Penyesuaian Mata Pelajaran Akuntansi Kelas XI IPS di SMA Negeri 1 Bae Kudus. Economic Education Analysis Journal, 1(2), 17.

Syuhada, E. H. (2012). Pengaruh Pemberian Tugas Terstruktur terhadap Hasil Belajar Geografi Siswa Kelas X MA Negeri Kandat Kediri. Skripsi, Universitas Negeri Malang, Indonesia.

Usman, M. (2008). Strategi Pembelajaran. Jakarta: Erlangga.

Warsiyam. (2016). Pembelajaran Terstruktur dengan Pemberian Tugas dalam Peningkatan Prestasi Belajar IPS. Didaktikum : Jurnal Penelitian Tindakan Kelas, $17(3), 62-68$. 